\title{
Implications of ceasing annual superphosphate topdressing applications on pasture production
}

\author{
S.D. MCBRIDE', M.L. NGUYEN' and D.S. RICKARD ${ }^{3}$ \\ ${ }^{1} M A F$ Technology, Winchmore Research Station, Private Bag, Ashburton \\ ${ }^{2} M A F$ Technology, Canterbury Agriculture \& Science Centre. Lincoln \\ ${ }^{3} 252$ Tancred Street, Ashburton
}

\begin{abstract}
Two field-plot trials were superimposed on irrigated, sheep-grazed pastures on Lismore stony silt loam in Canterbury to investigate residual effects of previous superphosphate applications on dry matter (DM) production and herbage composition. Residual effect of

was attributed to $\mathrm{S}$ deficiency in clover while $\mathrm{P}$ deficiency in grass and clover was not apparent until the 4 th year after the cessation of superphosphate application. The results were used in a simple model that uses previous topdressing history to predict yield reductions if topdressing is withheld.
\end{abstract} phosphorus (P) in superphosphate was shown to depend upon previous application rate and number of years of superphosphate application. In contrast, residual effect of sulphur (S) in superphosphate was independent of previous application rate if superphosphate had been applied for 25 years at rates at or above the $S$ maintenance rate. Previous applications of superphosphate at the annual rate of $376 \mathrm{~kg} / \mathrm{ha}$ for 6 years failed to safeguard pasture against yield reduction even in the first year after superphosphate was discontinued. This reduction was attributed equally to both $\mathrm{P}$ and $\mathrm{S}$ deficiencies. Residual values of both $\mathrm{P}$ and $\mathbf{S}$ were more substantial in areas where superphosphate had been-applied-at--the-higher rate of $564 \mathrm{~kg} / \mathrm{ha}$ for 6 years. However, these residual values were also short-lived and DM production declined by $13 \%$ in the second year after the cessation of superphosphate application. Different patterns of residual values of superphosphate were recorded on areas where superphosphate had been applied over a longer term of 25 years. Where superphosphate had been applied annually at $188 \mathrm{~kg} / \mathrm{ha}$, DM production fell by $10 \%$ in the first year after topdressing ceased. This reduction was due entirely to $\mathrm{P}$ deficiency affecting clover growth, while $\mathbf{S}$ deficiency - in both grass and clover - was not observed until the third year after topdressing ceased. On areas where superphosphate had been applied at a higher rate of $376 \mathrm{~kg} / \mathrm{ha}$ for a similar period of 25 years, DM production did not decline until the second year. This initial decline

Keywords residual effects, phosphorus, sulphur, irrigated pasture

\section{Introduction}

The downturn in the agricultural economy in recent years forced many farmers to reduce or withhold superphosphate applications. The effect of these actions on pasture or animal production often depends on the residual values of both phosphorus (P) and sulphur (S) components of superphosphate (Saunders \& Cooper 1983; Quinn \& Scobie 1985). These residual values under hill country and dairy farm situations have been recently reported by various workers (Gillingham et al. 1989; Lambert et al. 1989; O'Connor et al 1985).

However, these reported results are likely to be different from those occurring on irrigated pastures in Canterbury because of different levels of pasture or animal production, excretal transfer, and $\mathbf{S}$ leaching losses on the different soil types, topography, and management (Cornforth \& Sinclair 1984; Sinclair \& Saunders 1984).

This paper reports on the residual effect on production of irrigated pasture when topdressing was withheld after both short-term (6 years) and longterm (25 years) applications of superphosphate.

\section{Methods}

The long-term fertiliser trial (Rickard \& McBride 1987; Nguyen et al. 1989) at Winchmore Research Station on a Lismore stony silt loam (Udic Ustochrept) provided suitable sites for the investigation of the residual effects of superphosphate. This trial was conducted on a grazed, irrigated perennial ryegrass-white clover pasture. 
Two trials were carried out to provide information on the effects of ceasing topdressing of either $\mathrm{P}$ or $\mathrm{S}$ or both $\mathrm{P}$ and $\mathrm{S}$ on pasture production. Both trials were mown with clippings returned. The effects on botanical composition were also assessed in pastures where superphosphate had been applied for 25 years. Trial A

A small plot trial $(4.5 \times 0.76 \mathrm{~m}$ per plot $)$ was established in 1958 on pasture that had received superphosphate for 6 years at two annual rates: 376 and $564 \mathrm{~kg} / \mathrm{ha}$. Average annual DM yields on these areas were 10.9 and 11.4 tha respectively (Rickard \& McBride 1987). Treatments on the small-plot trial included no fertiliser, applied $\mathrm{P}$ only, applied $\mathrm{S}$ only, and $\mathrm{P}$ plus $\mathrm{S}$. Phosphorus was applied as monocalcium phosphate at $34 \mathrm{~kg} \mathrm{P} / \mathrm{ha}$ and $\mathrm{S}$ as gypsum at $41 \mathrm{~kg} \mathrm{~S} / \mathrm{ha}$, equivalent to $376 \mathrm{~kg} / \mathrm{ha}$ superphosphate. This trial had a split-plot design with 4 reps and ran for 4 years.

\section{Trial B}

A small plot trial $(4.5 \times 0.76 \mathrm{~m}$ per plot) was established in 1977 on pasture that had received superphosphate at 188 and $376 \mathrm{~kg} / \mathrm{ha}$ each year for 25 years. Average DM yields on these areas were 9.8 and 11.1 tha respectively (Rickard \& McBride 1987). As in trial $\mathrm{A}$, treatments included no fertiliser, $\mathrm{P}$ only, $\mathrm{S}$ only, and $\mathrm{P}$ plus $\mathrm{S}$, applied as monocalcium phosphate and gypsum. Results reported from this second trial are from treatments that received $\mathrm{P}$ and $\mathrm{S}$ at annual rates equivalent to their previous superphosphate topdressing history: 188 or 376 $\mathrm{kg} / \mathrm{ha}$. This trial had a split-plot design with 4 reps and ran for 6 years.

\section{Results and discussion}

\section{Residual effects of previous superphosphate applications}

Residual value of superphosphate applications was measured by the extent of the decline in DM production with time after superphosphate application was withheld. On areas where superphosphate had been applied for 6 years at 376 $\mathrm{kg} / \mathrm{ha}$, the decrease in DM (relative to that of the continuous application) in the first and second year after cessation was $15 \%$ and $31 \%$ respectively (Figure 1). However, DM reduction was less severe in the area that previously received superphosphate at $564 \mathrm{~kg} / \mathrm{ha}$, and did not reach significance until the second year (Figure 1).

On areas where superphosphate had been applied over the longer period, the residual effect of previous superphosphate application was also shown to depend on previous topdressing history. After 25 years of applications of $188 \mathrm{~kg} / \mathrm{ha}$ superphosphate, the decrease in DM production was $10 \%$ in the first year after topdressing ceased (Figure 1). This decrease was due entirely to a reduction in clover growth (Table 1). In the second year. the decline in

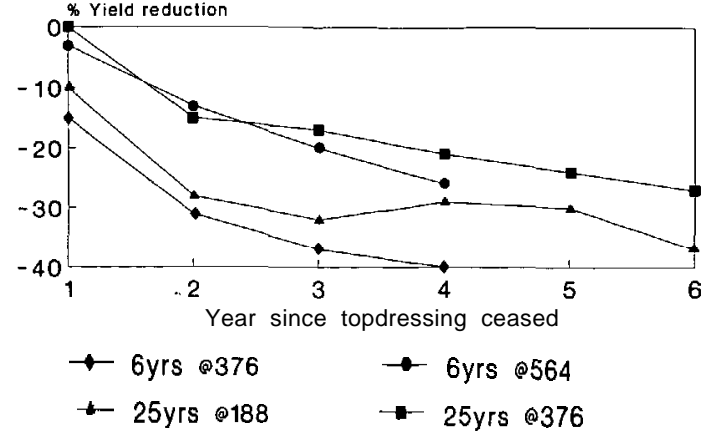

Figure 1 Dry matter yield reduction $(\mathbf{0})$ with time, on plots that received no $\mathrm{P}$ or $\mathbf{S}$ fertiliser after superphosphate had been applied annually for 6 years at 376 or $564 \mathrm{~kg} / \mathrm{ha}$ and 25 years at 188 or $376 \mathrm{~kg} / \mathrm{ha}$.

DM production had increased to $28 \%$ (Figure 1), and this decline was due to an equal decrease in both grass and clover production (Table 1). In contrast, DM production did not decrease in the 1st year on the area that previously received superphosphate at $376 \mathrm{~kg} / \mathrm{ha}$; even in year 6 after the cessation of superphosphate application, the decrease was only $27 \%$ (Figure 1). The decline in DM production in the second year was due mainly to a reduction of the clover component (Table 1).

These results indicate that there was a substantial residual value of previously applied superphosphate, especially when superphosphate was applied for long periods at rates which were considered to be above superphosphate maintenance requirements (250 $\mathrm{kg} /$ ha/year) (Nguyen et al. 1989). The residual value of a superphosphate may have been from either $\mathrm{P}$ or $\mathrm{S}$, or both $\mathrm{P}$ and $\mathrm{S}$.

Residual value of sulphur from superphosphate

The residual effect of the $S$ component of superphosphate was shown by the extent of the decrease in DM production in areas where only $\mathrm{P}$ was applied after the cessation of superphosphate application.

Residual values of $\mathrm{S}$ from short-term (6 years) superphosphate applications were shown to depend on previous application rate. On areas that previously received superphosphate at $376 \mathrm{~kg} / \mathrm{ha}$, the decrease in DM production in P-applied plots relative to the continuous application was $11 \%$ in the first year (Figure 2). DM production continued to decline with time, reaching $37 \%$ in the fourth year (Figure 2). In contrast, application of $P$ alone after 6 years of superphosphate topdressing at $564 \mathrm{~kg} / \mathrm{ha}$ was able to sustain pasture production until the second year (Figure 2).

After 6 years of superphosphate application, the magnitude of yield reduction in plots where there was a continued $\mathrm{P}$ application (Figure 2) was similar to that in plots where both $\mathrm{P}$ and $\mathrm{S}$ were withheld (Figure 1). This suggests that $\mathrm{S}$ deficiency is a more limiting factor for pasture growth than $\mathrm{P}$ deficiency 
Table 1 Dry matter reduction that occurred in subsequent years following the cessation of 25 years of superphosphate (SP) topdressing. (Expressed as a $\%$ reduction relative to the continuous treatment).

\begin{tabular}{|c|c|c|c|c|c|c|c|c|}
\hline \multirow{2}{*}{$\begin{array}{ll}\text { Fertiliser input } & \text { after } \\
\text { superphosphate } & \text { discontinued }\end{array}$} & \multirow{2}{*}{$\begin{array}{c}\text { Previous } \\
\text { application rate }\end{array}$} & \multirow{2}{*}{$\begin{array}{l}\text { Herbage } \\
\text { component }\end{array}$} & \multicolumn{2}{|c|}{ Year after } & \multicolumn{2}{|c|}{ superphosphat } & \multicolumn{2}{|c|}{ withheld } \\
\hline & & & 1 & 2 & 3 & 4 & 5 & 6 \\
\hline \multirow{2}{*}{ No $P$ no $S$} & 188 & $\begin{array}{l}\text { grass } \\
\text { clover }\end{array}$ & $\stackrel{2}{27}$ & $\begin{array}{l}33 \\
35\end{array}$ & $\begin{array}{l}38 \\
45\end{array}$ & $\begin{array}{l}35 \\
46\end{array}$ & $\begin{array}{l}38 \\
49\end{array}$ & $\begin{array}{l}53 \\
55\end{array}$ \\
\hline & 376 & $\begin{array}{l}\text { grass } \\
\text { clover }\end{array}$ & $\begin{array}{r}0 \\
12\end{array}$ & $\begin{array}{l}7 \\
38\end{array}$ & $\begin{array}{l}23 \\
27\end{array}$ & $\begin{array}{c}27 \\
42\end{array}$ & $\begin{array}{l}36 \\
28\end{array}$ & $\begin{array}{l}45 \\
34\end{array}$ \\
\hline \multirow{2}{*}{ P only } & 188 & $\begin{array}{l}\text { grass } \\
\text { clover }\end{array}$ & $\begin{array}{c}0 \\
16\end{array}$ & $\begin{array}{l}9 \\
15\end{array}$ & $\begin{array}{c}21 \\
22\end{array}$ & $\begin{array}{c}19 \\
19\end{array}$ & $\begin{array}{c}29 \\
27\end{array}$ & $\begin{array}{l}28 \\
26\end{array}$ \\
\hline & 376 & $\begin{array}{l}\text { grass } \\
\text { clover }\end{array}$ & $\begin{array}{l}0 \\
0\end{array}$ & $\begin{array}{l}5 \\
24\end{array}$ & $\begin{array}{l}15 \\
25\end{array}$ & $\begin{array}{l}17 \\
22\end{array}$ & $\begin{array}{l}20 \\
12\end{array}$ & $\begin{array}{r}26 \\
8\end{array}$ \\
\hline \multirow{2}{*}{ S only } & 188 & $\begin{array}{l}\text { grass } \\
\text { clover }\end{array}$ & $\begin{array}{c}0 \\
39\end{array}$ & $\begin{array}{l}18 \\
42\end{array}$ & $\begin{array}{l}31 \\
55\end{array}$ & $\begin{array}{l}35 \\
52\end{array}$ & $\begin{array}{l}42 \\
45\end{array}$ & $\begin{array}{l}50 \\
57\end{array}$ \\
\hline & 376 & $\begin{array}{l}\text { grass } \\
\text { clover }\end{array}$ & $\begin{array}{l}0 \\
0\end{array}$ & $\begin{array}{l}0 \\
0\end{array}$ & $\begin{array}{c}0 \\
0\end{array}$ & $\begin{array}{l}9 \\
5\end{array}$ & $\begin{array}{r}16 \\
7\end{array}$ & $\begin{array}{l}18 \\
23\end{array}$ \\
\hline
\end{tabular}
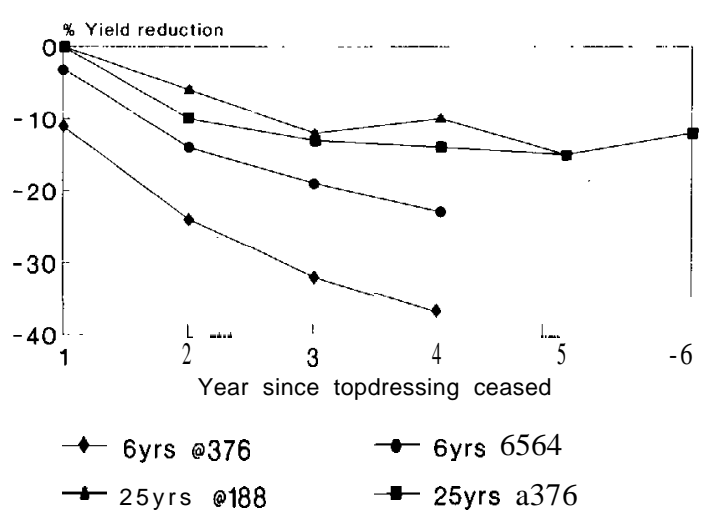

Figure 2 Dry matter yield reduction $(\%)$ with time, on plots that received $P$ only as fertiliser after superphosphate had been applied annually for 6 years at 376 or $564 \mathrm{~kg} / \mathrm{ha}$ and 25 years at 188 or $376 \mathrm{~kg} / \mathrm{ha}$.

in areas where superphosphate had been applied for only 6 years at either 376 or $564 \mathrm{~kg} / \mathrm{ha}$.

In areas where superphosphate had been applied for over 25 years at 188 or $376 \mathrm{~kg} / \mathrm{ha}$, the residual value of $\mathrm{S}$ from superphosphate was substantial. When $\mathrm{P}$ only was applied, DM yield did not decrease in the first year. In subsequent years, production declined but levelled out at about $12 \%$ down, again with no difference between previous application rates (Figure 2). Dry matter reduction in the second year was due entirely to a decrease in clover growth (Table 1). A reduction of over $10 \%$ in grass production did not occur until the third year (Table 1).

Residual values of $S$ from superphosphate from both short- and long-term applications may be attributed to the mineralisation-immobilisation of soil organic S (Nguyen \& Goh 1990). In areas where superphosphate had been applied for 6 years, the accumulation of soil organic $\mathrm{S}$ had not reached a steady state (Nguyen \& Goh 1990) and the rate of $\mathrm{S}$ mineralisation probably depended on the particular level of organic S reached in the soil (Ghani 1989). However, the rates of $\mathrm{S}$ mineralisation in areas where superphosphate had been applied for 25 years at 188 or $376 \mathrm{~kg} / \mathrm{ha}$ may be similar, since soil organic $\mathrm{S}$ in both areas has been reported to attain a similar equilibrium level (Nguyen \& Goh 1990). This could explain the similar residual value of $S$ in these areas.

Residual value of phosphorus from superphosphate The residual effect of $\mathrm{P}$ from superphosphate was shown by the extent of the decline in DM yield in areas where $\mathrm{S}$ only was applied after superphosphate application were discontinued.

Application of $S$ alone after 6 years of superphosphate at $376^{-} \mathrm{kg} / \mathrm{ha}$ fäiled to sustain a pasture against yield reduction even in the first year (Figure 3). However, only a small yield reduction occurred on areas where only $S$ was applied after the application of $564 \mathrm{~kg} / \mathrm{ha}$ superphosphate was discontinued (Figure 3). This suggests that residual $\mathrm{P}$ in the area previously applied with $564 \mathrm{~kg} / \mathrm{ha}$ was substantial, probably because of the contribution from inorganic and organic P reserves (Goh \& Condron 1989; Condron \& Goh 1990).

In areas where superphosphate had been applied for 25 years, residual $\mathrm{P}$ from $188 \mathrm{~kg} / \mathrm{ha}$ was unable to sustain pasture production against yeild reduction even in the first year (a 14\% decline) after topdressing ceased (Figure 3). There was a substantial $(39 \%)$ reduction in clover, but grass production was not affected by the absence of $\mathrm{P}$ applications until the second year (Table 1).

In contrast, there was a substantial residual of $\mathrm{P}$ from superphosphte applied for 25 years at the higher rate of $376 \mathrm{~kg} / \mathrm{ha}$. Where no $\mathrm{P}$ was applied no significant decrease in DM yield or change in herbage composition occurred until the fifth year after the 


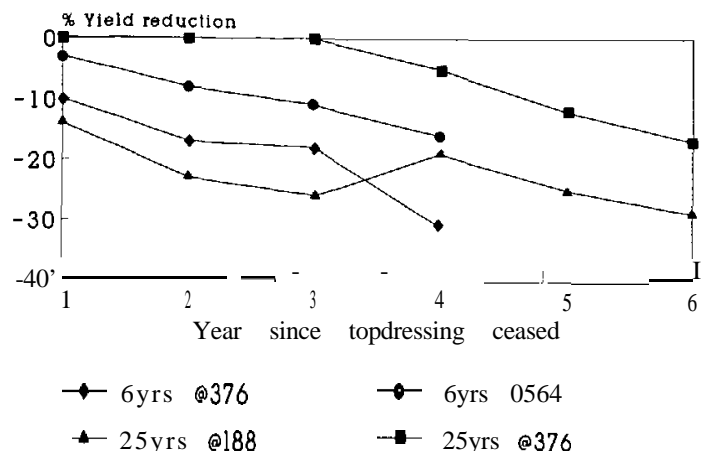

Figure 3 Dry matter yield reduction $(\mathbf{\%})$ with time, on plots that received $\mathbf{S}$ only as fertiliser after superphosphate had been applied annually for 6 years at 376 or $564 \mathrm{~kg} / \mathrm{ha}$ and 25 years at 188 or $376 \mathrm{~kg} / \mathrm{ha}$.

cessation of superphosphate (Figure 3; Table 1). The higher residual value of $\mathrm{P}$ from the $376 \mathrm{~kg}$ superphosphate application rate probably reflects the higher soil inorganic $\mathrm{P}$ reserve in this treatment (Nguyen et al 1989).

\section{Predictive model for assessing DM reduction after superphosphate cessation}

A multiple regression analysis model was constructed to predict yeild reductions due to withholding superphosphate applications on irrigated pasture on Lismore silt loam. This model accounted for previous topdressing history and the number of years topdressing was withheld.

\section{DMreduct $=47.7-0.08 *$ Prev $-0.92 * \mathrm{Nuyr}$$$
+14.6^{*} \log (\mathrm{Yr})
$$$$
\mathbf{R}^{2}=0.923 * *
$$

Where:

DMreduct $=\%$ reduction in DM production after the cessation of superphosphate application compared with production from continued application.

Prev $=$ the annual amount $(\mathrm{kg} / \mathrm{ha})$ of superphosphate previously applied

Nuyr $=$ number of years at this topdressing rate

$\mathrm{Yr}=$ number of years since topdressing ceased

Further work on this model is required, in particular, separation of the residual effects of the $\mathrm{P}$ and $\mathbf{S}$ components of superphosphate.

\section{ACKNOWLEDGEMENTS}

Technical staff at Winchmore over a number of years; in particular Mr G.N. Green.

\section{REFERENCES}

Condron, L.N.; Goh, K.M. 1990. Nature and availability of residual phosphorus in long term fertilised pasture soils in New Zealand. Journal of agricultural science, Cambridge 114: 1-9.

Cornforth, I.J.; Sinclair, A.G. 1984. Pp 10-13 In Fertiliser recommendations for pastures and crops in New Zealand. Pasture maintenance, phosphorus. Second revised edition. New Zealand Ministry of Agriculture and Fisheries. Agricultural Research and Advisory Services Divisions, Wellington, New Zealand.

Ghani, A. 1989. Role of soil organic sulphur in supplying sulphate for plant growth. Unpublished PhD thesis, University of Canterbury (Lincoln College).

Gillingham, A.G.; Richardson, S.; Power, I.L.; Riley, J. 1989: Long term effects of withholding phosphate application on North Island hill country: Whatawhata Research Centre. Proceedings of the NZ Grassland Association 50: 11-16.

Goh, K.M.; Condron, L.M. 1989: Plant availability of phosphorus accumulated from long-term applications of superphosphate and effluent to irrigated pastures. NZ journal of agricultural research 32: 45-5 1.

Lambert, M.G.; Clark, D.A.; Makay, A.D. 1989: Long term effects of witholding phosphate application on North Island hill country: Ballantrae. Proceedings of the NZ Grassland Association 50: 25-28.

Nguyen, M.L.; Rickard, D.S.; McBride, S.D. 1989: Pasture production and changes in phosphorus and sulphur status in irrigated pastures receiving long-term applications of superphosphate fertiliser. NZ journal of agricultural research 32: 245-262.

Nguyen, M.L.; Goh, K.M. 1990. Accumulation of soil sulphur fractions in grazed pastures receiving longterm superphosphate applications: NZ journal of agricultural research 33: 111-128.

O'Connor, M.B.; Shannon, P.W.; Gillingham, A.G. 1985 The effects of withholding fertiliser on pastoral production on hill country. Proceedings of the 20th Technical Conference of the New Zealand Fertihser Manufacturer's Research Association: 260-273.

Rickard, D.S.; McBride, S.D. 1987. Long term application and residual effects of superphosphate and effects of reactive phosphate rock on irrigated pasture. Winchmore Irrigation Research Station technical report No. 22. Winchmore Irrigation Research Station. New Zealand Ministry of Agriculture and Fisheries.

Quin, B.F.; Scobie, G.M. 1985. Getting the best returns from fertiliser expenditure. Proceedings of the 37th Ruakura Farmers' Conference: 42-54.

Saunders, W.M.H.; Cooper, D.M. 1983. Sulphur responses of pasture and lucerne in New Zealand. Pp 61-72. In Proceedings of the technical workshop on sulphur in New Zealand agriculture, Gregg, P.E.H.; Syers, J.K. (eds) Department of Soil Science, Massey University, Palmerston North, New Zealand.

Sinclair, A.G.; Saunders, W.M.H. 1984. Pp 15-17 In Fertiliser recommendations for pastures and crops in New Zealand. Pasture maintenance, sulphur. Second revised edition. New Zealand Ministry of Agriculture and Fisheries. Agricultural Research and Advisory Services Divisions, Wellington, New Zealand. 